\title{
Organizational Communication, Job Stress and Citizenship Behaviour of IT Employees in Nigerian Universities
}

\author{
Fidelis Aondoaseer Ayatse $(\mathrm{PhD})$ \\ Department of Business Administration \\ College of Management Sciences \\ University of Agriculture, Makurdi, Nigeria \\ Darius Ngutor Ikyanyon (Corresponding Author) \\ Department of Business Management \\ Benue State University, Makurdi, Nigeria \\ E-mail: ikyanyondarius@gmail.com
}

Received: June 23, 2012

doi:10.5430/jbar.v1n1p99
Accepted: July 10, 2012

Online Published: July 11, 2012

\begin{abstract}
The study examined the relationship among organizational communication, job stress, and citizenship behaviour of IT employees in Nigerian universities and investigated if differences existed in the rating of these variables between federal and state university employees. Data were collected from IT employees in University of Agriculture Makurdi and Benue State University Makurdi $(\mathrm{n}=49)$. Using Pearson correlation coefficient, $\mathrm{t}$-test and regression model as tools of data analysis, the study found that there was no difference in organizational communication and stress levels between IT employees in federal and state universities. However, differences existed in citizenship behaviour between the two samples, with IT employees in the state university showing higher levels of citizenship behaviour. The study also found a significant positive relationship between organizational communication and citizenship behaviour while stress levels were not found to be related to either organizational communication or citizenship behaviour. The implications of the findings were discussed with recommendations made.
\end{abstract}

Keywords: Stress, Communication, Citizenship, Information Technology, Universities, Nigeria

\section{Introduction}

Attention has been given to the study of organizational communication, job stress and citizenship behaviour in organizational behaviour research as a result of the significance of these variables to organizational effectiveness. For instance, it has been found that effective communication improves job satisfaction (Holtzhausen, 2002) and improves productivity (Litterst \& Eyo, 1982). Research has also shown that communication improves employee job performance (Goris, 2007). Poor communication on the other hand results to low employee commitment to the organization (Kramer, 1999). Since citizenship behaviour is an aspect of job performance (Fisher, 2003), it therefore means that communication affects citizenship behaviour (Kandlousi et al., 2010). Similarly, citizenship behaviour contributes to organizational effectiveness (Bolino et al., 2002) while job stress has an effect on citizenship behaviour (Bolino \& Turnley, 2005).

Communication is the transfer of information from a sender to a receiver, with the message being understood by the receiver. Price (1997) defined organizational communication as the degree to which information about the job is transmitted by an organization to its members and among members of the organization. Ayatse (2005) observed that communication is needed to establish and disseminate the goals of the enterprise. Chen et al. (2006) pointed out that research is lacking in examining employee satisfaction with communication process. There is therefore the need to explore the relationship between organizational communication and organizational variables since communication integrates different units and functions in the organization.

Citizenship behaviour is defined as individual behaviour that is discretionary, not directly or explicitly recognized by the formal reward system, and that in the aggregate promotes the effective functioning of the organization (Organ, 
1988). Citizenship behaviour is discretionary in the sense that employees are not required formally by the organization to exhibit such behaviours but do so out of their own volition. It entails going beyond an employee's work schedule to perform other duties that could help achieve organizational effectiveness. As Podsakoff et al. (2000) points out, employees are not punished for failure to exhibit citizenship behaviour. Research has shown that citizenship behaviour affects organizational variables such as performance of sales force (Malik et al., 2011), job satisfaction and commitment (Davis, 1992).

Studies on job stress indicate that severe job stress is dysfunctional and decreases commitment and productivity (Montgomery et al., 1996). Similarly, Park (2007) observed that the negative implications of job stress are recognized as a challenge to both employers and workers. Rees (1995) found that the relationship between stress and employee attitudes such as job satisfaction can differ, depending on the group being investigated. This means that the effect of stress on employee attitude and behaviour is relative. Bolino and Turnley (2005) report a positive relationship between job stress and citizenship behaviour.

Okpara (2007) argued that information technology (IT) is seen as the means to improve organizational performance and productivity. In the university system, IT facilitates teaching and learning as well as effective conduct of research and university administration generally. Womboh (2003) observed that IT in most Nigerian universities is mediocre and insists that universities without a functional IT connectivity will eventually become extinct and obsolete. Meanwhile, Okpara (2007) maintained that to deal with the enormous growth in IT, organizations must compete to hire and retain the brightest people they can find. Since IT is very essential to the functioning of the university system, there is therefore the need to study how work variables such as organizational communication and job stress affect citizenship behaviour of IT employees in Nigerian universities.

\section{Literature Review}

\subsection{Organizational Communication}

Communication is the human activity that links people together and create relationship (Duncan \& Moriaty, 1998). This means that individuals relate with each other by means of communication. It is a glue that binds people together in an organization. Different units exist in an organization and it is through communication that interaction takes place for the attainment of organizational goals. Cooren (1999) asserts that communication constitutes the action of the organization and the works of organizing, coordinating, informing, arranging, staffing, and other functions of management. Communication is vital in organizations such that Orpen (1997) argued that communication has a vital role in the failure or accomplishment of any organization.

Communication in the organization can be formal or informal (Kandlousi et al, 2010). Formal communication channels are recognized formally or originally by the organization. Formal communication follows the formal structure or hierarchy of the organization (Guffy et al, 2005) and can flow in downward, upward, and cross-wise directions (Ayatse, 2005). Downward communication flows from people at higher levels to those at lower levels in the organization hierarchy; upward communication travels from subordinates to superiors and continues up the organizational hierarchy; while cross-wise communication flows among people on the same organizational levels, and among people at different levels who have no direct reporting relationships with one another. Informal communication on the other hand is based on social relationships (Guffy et al, 2005) and is inevitable in organizational life (Crampton et al, 1998). Informal communication channels such as grapevine and gossips often fill the gaps that formal communication fails to address (Gilsdorf, 1998). While informal communication originates to serve employees' private purposes, formal communication is supposed to serve the purpose of the organization (Ogaard et al, 2008). On the whole, both forms of communication are important and should be managed properly to enhance organizational effectiveness.

\subsection{Citizenship Behaviour}

Citizenship behaviour has being defined as a set of discretionary workplace behaviours that exceeds one's basic job requirements. These behaviours are often described as going beyond the call of duty (Jahangir et al., 2004). Citizenship behaviour has received serious attention in organizational behaviour research as a result of its benefits to individuals and organizations. It has been conceptualized as altruism, conscientiousness, sportsmanship, courtesy, and civic virtue (Organ, 1988). Citizenship behaviour is vital since employees go beyond their formal job responsibilities and freely give their time and energy to succeed at the assigned job.

The definition of citizenship behaviour as discretionary, extra, and beyond the job requirements is however not without controversy, as Morrison (1994) observed that citizenship behaviour is ill-defined and varies from one employee to the other and between employees to supervisors. This means that what is an extra-role or beyond the job 
requirements to one supervisor or employee might be considered an "in-role" to another supervisor or employee in the same organization. We can rightly conclude that the definition and meaning of citizenship behaviour is subjective. In his construct clean-up time of citizenship behaviour, Organ (1997 p. 87) argued that "the problem noted with citizenship behaviour defined as discretionary, extra, and beyond the job requirements is that, citizenship behaviour, as measured, contains elements that many observers (even respondents themselves) would consider part of the job". Organ (1997) concluded that it would be preferable to avoid, if it is possible, reference to extra-role behaviour in defining citizenship behaviour.

In a meta-analytical review of attitudinal and dispositional predictors of citizenship behaviour, Organ and Ryan (1995) concluded that job attitudes such as job satisfaction, perceived fairness, organizational commitment, and leader supportiveness are robust predictors of citizenship behaviour. However, the effect of organizational communication on citizenship behaviour is not well explored in the literature. Much of the attention has been focused on the effect of organizational communication on job performance. However, Fisher (2003) argue that citizenship behaviour is an aspect of job performance, therefore, since organizational communication has been found to influence job performance (Goris, 2007; Koys, 2001), it then means organizational communication has an influence on citizenship behaviour. The study of citizenship behaviour is hinged on social exchange theory which argues that people reciprocate the advantages they receive from their organization (Kandlousi et al., 2010). It is therefore worthy to conclude that employees who are satisfied with the communication process in their organization will try to reciprocate by engaging in citizenship behaviour (Bolino, 1999).

\subsection{Job Stress}

Job stress is the harmful physical and emotional responses that occur when job requirements do not match the worker's capabilities, resources and needs (Park, 2007). The experience of stress at work cuts across organizations, irrespective of industry and size (Fletcher, 1998) and studies have shown that job stress decreases well being in the workplace (Danna \& Griffin, 1999). Several aspects of organizational life have been linked to stress. Aspects of the work itself such as work overload (Sparks \& Cooper, 1999), role conflict, lack of power, and role ambiguity (Nelson $\&$ Burke, 2000) can be stressful. The behaviour of the leader (Carlopio et al, 1997) as well as the quality of the social environment in the workplace are associated with stress (Fairbrother \& Warn, 2003). Similarly, physical conditions such as overcrowding in the workplace, lack of privacy, or high noise levels have been associated with stress (Park, 2007). Also the conflict between family life and work and the impact of work on personal relationships is stressful (Nelson \& Burke, 2000).

A few studies that have examined the relationship between job stress and citizenship behaviour have reported mixed findings. For instance, Motowidlo et al. (1986) report a negative relationship between job stress and citizenship behaviour while Bolino and Turnley (2005) found a positive relationship between these variables. However, Pallie (2011) found no relationship at all between job stress and citizenship behaviour. This present study seeks to examine this relationship further, using the Nigerian work environment.

\section{Research Method}

\subsection{Hypotheses}

The purpose of the study was to determine the relationship among organizational communication, job stress, and citizenship behaviour of IT employees in Nigerian universities, and to investigate whether there are differences in the levels of citizenship behaviour, organizational, and job stress between IT employees in federal and state universities in Nigeria. Consequently, the following hypotheses were formulated and tested for the study:

H1. Organizational communication is positively related to citizenship behaviour of IT employees in Nigerian universities.

H2. Organizational communication is inversely related the job stress of IT employees in Nigerian universities.

H3. Job stress is inversely related to citizenship behaviour of IT employees in Nigerian universities

H4. There are differences in the levels of citizenship behaviour, organizational communication and job stress between IT employees in federal and state universities in Nigeria.

\subsection{Participants}

Data were collected from IT employees from University of Agriculture, Makurdi which is a federal university and Benue State University, Makurdi, being a state university. IT employees were defined as those employees in Nigerian universities who work under the information and communication technology (ICT) unit or directorate as the case may be, and are involved in IT management, computer networks, system development and integration, technical 
service and operations, PC end-user support, and all such issues relating to information and communication technology in these universities. Since differences exist in the physical working conditions between federal and state universities in Nigeria, we expect that measures of organizational communication, citizenship behaviour, and job stress will differ between respondents in federal and state universities.

A total of 49 questionnaires were distributed to IT employees in University of Agriculture, Makurdi and Benue State University, Makurdi. Out of this number, 31 were from University Agriculture Makurdi while 18 were from Benue State University, Makurdi. Of the sample from University of Agriculture Makurdi, 19 (61.29\%) were males while 12 $(38.71 \%)$ were females. As for the sample from Benue State University, $10(55.56 \%)$ were males while $8(44.44 \%)$ were females.

\subsection{Instruments}

The constructs for the study are organizational communication, job stress, and citizenship behaviour. Organizational communication was measured based on the supervisor-subordinate scale developed by Penley and Hawkins (1985) which is a 19-item six-point Likert type scale and measures communication on five dimensions which are: task, performance, career, personal communication, and communication responsiveness. Job stress was measured using the job stress scale by Montgomery et al.(1996). The scale adopts a five-point Likert type measure and has six items measuring job stress. Citizenship behaviour was measured using the sixteen-item five-point Likert scale developed by Lee and Allen (2002). The coefficient alpha reliabilities of the scales (organizational communication, job stress, and citizenship behaviour) were $.79, .74$, and .81 respectively.

\section{Results}

Pearson product correlations computed between organizational communication, job stress, and citizenship behaviour indicate that there was a significant and positive relationship between organizational communication and citizenship behaviour $(r=.32, p<.01)$, which is in line with the findings of Kandlousi et al. (2010). However, the relationship was not significant and negative between organizational communication and job stress $(r=-1.09, p>.05)$. This finding corresponds with that of Chen et al. (2006).

Similarly, no significant relationship was found between job stress and citizenship behaviour $(r=-.07, p>.05)$ and agrees with the findings of Motowidlo et al.(1986). The gender of respondents however, showed no differences in results obtained.

The results of independent t-test for differences between respondents from federal and state universities show that there was a significant difference in their ratings of citizenship behaviour $(t=-4.26, \mathrm{df}=47, p<.01)$. However, there was no significant difference in their rating of organizational communication $(t=.89, \mathrm{df}=47, p>.05)$ and job stress $(t=-1.54, \mathrm{df}=47, p>.05)$.

A one-way analysis of variance was also computed to determine the difference between samples from federal and state university for each of the three variables measured. There was no difference for organizational communication and job stress scales but for citizenship behaviour, the respondents in federal university reported a lower level of citizenship behaviour than did those in the state university $\left(F_{1,45}=8.38, p<.01\right)$.

Correlations computed separately for the two samples show that for IT employees in the federal university, organizational communication and citizenship behaviour were positively related $(r=.58, p<.01)$. The relationship between organizational communication and job stress was statistically insignificant $(r=-.42, p>.05)$. The same relationship was found between job stress and citizenship behaviour $(r=-.22, p>.05)$. For the sample in state university, organizational communication and citizenship behaviour were positively correlated $(r=.60, p<.01)$. The relationship between organizational communication and job stress, as well as job stress and citizenship behaviour were not significant $(r=-.41, p>.05)$ and $(r=-.19, p>.05)$ respectively.

A linear regression used to analyze the relationship between organizational communication and citizenship behaviour shows that with an increase in organizational communication by one unit, citizenship behaviour is increased by .08 units $\left(R^{2}=.05, F=8.03, p<.01\right)$. As for the relationship between job stress and citizenship behaviour, we utilized both linear and non-linear regression measure. It was found that job stress was not a predictor of changes in citizenship behaviour of IT employees in Nigerian universities. However, job stress predicted citizenship behaviour under the non-linear regression model $\left(R^{2}=.07, F=6.02, p<.05\right)$.

\section{Implications}

This study shows that organizational communication is an important predictor of citizenship behaviour of IT employees in Nigerian universities. This means that the citizenship behaviour of employees will be heightened when 
they are satisfied with the communication channels and processes in the organization. IT managers should therefore ensure that communication channels and processes are strengthened in order to elicit citizenship behaviour from employees.

The study also indicates no significant relationship between organizational communication and job stress of IT employees in Nigerian universities. While stress can be managed and consequently reduced, the study suggests that the level of stress cannot be reduced by strengthening the process and channels of communication in the organization.

Furthermore, the study shows that there is no significant relationship between job stress and citizenship behaviour of IT employees in Nigerian universities. The U-shaped nature of the non-linear regression model of the relationship between job stress and citizenship behaviour indicated that IT employees in Nigerian universities exhibit lower levels of citizenship behaviour with both high and low levels of job stress. A moderate level of job stress however resulted in more citizenship behaviour, which clearly indicates that IT employees in Nigerian universities appear to respond positively with moderate levels of job stress but poorly when stress is both high and low.

Lastly, the study shows a difference in the levels of citizenship behaviour between IT employees in the federal and state universities in Nigeria. The difference in citizenship behaviour between the two samples is worth emphasizing since the higher level of citizenship behaviour demonstrated by IT employees in the state university could be due to the fact that most of the employees were Benue indigenes and viewed the university as "their own". This enabled them offer help willingly to "their own" organization and could go out of their way to help their "brother" perform their task even when they were absent. In the federal university however, IT employees were from diverse ethnic backgrounds to reflect the federal character system of employment in the Nigerian public service. The implication is that the multi-ethnic nature of Nigeria affects the way employees relate with co-workers and the organization.

We therefore recommend that IT managers should encourage communication in the organization by creating a climate of trust, which facilitates open and honest communication. This will improve the citizenship behaviour of IT employees since communication is a predictor of citizenship behaviour.

Teamwork should be encouraged among IT employees in Nigerian universities as this will not only encourage interaction among employees, but facilitate communication among them and improve their citizenship behaviour.

IT mangers in Nigerian universities should design work processes such that IT employees do not experience high or low levels of stress. While it is necessary to reduce stress for instance, by clearly defining each task and assigning them to people with the relevant skills and competencies, the level of stress can be made moderate by making the job more challenging to employees.

Finally, IT mangers in Nigerian universities can take steps to help their workers better understand task objectives and reasons for performing certain tasks; help define the sequence in which subtasks should be performed; and provide their IT employees with clear definitions of individual tasks and overall job priorities.

\section{Conclusion}

The study examined the relationships among organizational communication, job stress, and citizenship behaviour of IT employees in Nigerian universities. Differences between IT employees in federal and state universities were investigated. Based on the findings, we conclude that that there is little or no difference in the levels of organizational communication and job stress irrespective of whether IT employees were from a federal or state university. However, differences existed in their levels of citizenship behaviour, with IT employees from the state university showing a higher level of citizenship behaviour.

We also conclude that there is a positive relationship between organizational communication and citizenship behaviour of IT employees in Nigerian universities. However, in line with previous studies the study finally concludes that there is no significant relationship between stress and citizenship behaviour. The non-linear relationship between stress and citizenship behaviour shows that not all levels of stress are dysfunctional since IT employees seem to respond poorly with both high and low levels of stress. However, their level of citizenship behaviour increased when the level of stress was moderate.

A major limitation of the study is the fact that a small sample size (49) was adopted for the study. The worth of this study would have improved greatly with the sample size increased to cover more IT employees in Nigerian universities. Notwithstanding, we strongly believe that this study has contributed to the pool of knowledge in the field of organizational behaviour. Further researchers should consider replicating the study and getting a larger number of participants either with more IT respondents or with other university groups. 


\section{Acknowledgements}

We are very thankful for the reviewers' comments and the editor's detailed suggestions that have helped improve the quality of the present paper greatly.

\section{References}

Ayatse, F. A. (2005). Management information system: A global perspective. Makurdi: Oracle.

Bateman, T. S. \& Organ, D. W. (1983). Job satisfaction and the good soldier: The relationship between affect and employee citizenship. Academy of Management Journal, 26, 587-595. http://dx.doi.org/10.2307/255908

Bolino, M. C. \& Turnley, W. H (2005). The personal cost of citizenship behaviour: the relationship between individual initiative and work overload, job stress, and work-family conflict. Journal of Applied Psychology, 90, 740-748. http://dx.doi.org/10.1037/0021-9010.90.4.740

Bolino, M. C. (1999). Citizenship and impression management: Good soldiers or good actors? The Academy of Management Review, 24(1), 82-98.

Bolino, M. C., Turnley, W. H. \& Bloodgood, J. M. (2002). Citizenship behaviour and the creation of social capital in organizations. Academy of Management Review, 27, 505-522.

Carlopio, J., Andreawartha, G. \& Armstrong, H. (1997). Developing Management Skills in Australia. Melbourne: Longman.

Chen, J., Silverthorne, C. \& Hung, J. (2006). Organizational communication, job stress, organizational commitment, and job performance of accounting professionals in Taiwan and America. Leadership \& Organizational Development Journal 27(4), 242-249. http://dx.doi.org/10.1108/01437730610666000

Cooren, F. (1999). The organizing property of communication. Amsterdam: John Benjamins.

Crampton, S. M., Hodge, J. W. \& Mishra, J. M. (1998). The informal communication network: Factors influencing grapevine activity. Public Personnel Management, 27(4), 569-584.

Danna, K. \& Griffin, R. (1999). Health and well-being in the workplace: a review and synthesis of the literature. Journal of Management, 25, 357-384. http://dx.doi.org/10.1177/014920639902500305

Davis, R. V. (1992). Person-environment fit and job satisfaction. In C. J. Cranny, P. C. Smith \& E. F. Stone (Eds.), Job satisfaction. NY: Lexington Books.

Duncan, T. \& Moriaty, S. E. (1998). A communication-based marketing model for managing relationships. Journal of Marketing, 62(2), 1-13. http://dx.doi.org/10.2307/1252157

Fairbrother, K. \& Warn, J. (2002). Workplace dimensions, stress and job satisfaction. Journal of Management Psychology, 18(1), 8-21. http://dx.doi.org/10.1108/02683940310459565

Fisher, D. C. (2003). Why do lay people believe that satisfaction and performance are correlated? Possible sources of a commonsense theory. Journal of Organizational Behaviour, 24(6), 753-777. http://dx.doi.org/10.1002/job.219

Fletcher, B. (1988). The epidemiology of occupational stress. In C. L. Cooper \& R. Payne (Eds), Causes, coping and consequences of stress at work. Chisester: John Wiley and Sons.

Gilsdorf, J. W. (1998). Organizational rules on communication: How employees are and are not learning the ropes. Journal of Business Communication, 35(2), 173-201. http://dx.doi.org/10.1177/002194369803500201

Goris, J. R. (2007). Effects of satisfaction with communication on the relationship between individual-job congruence and job performance/satisfaction. Journal of Management Development, 26(28), 737-752. http://dx.doi.org/10.1108/02621710710777255

Guffy, M. E., Rhoddes, K. \& Rogin, P. (2005). Business communication. Toronto: South-Western.

Holtzhausen, D. (2002). The effect of divisionalised and decentralized organizational structure on a formal internal communication function in a South African organization. Journal of Communication Management, 6(4), 323-339. http://dx.doi.org/10.1108/13632540210807152

Jahangir, N., Akbar, M. M. \& Haq, M. (2004). Organizational behaviour: Its nature and antecedents. BRAC University Journal, 1(2), 75-85.

Kandlousi, N. S., Ali, A. J. \& Abdollahi, A. (2010). Organizational citizenship behaviour in concerno f communication satisfaction: The role of the formal and informal communication. International Journal of Business and Management, 5(10), 51-61. 
Koys, D. J. (2001). The effects of employee satisfaction, organizational citizenship behaviour, and turnover on organizational effectiveness: A unit level, longitudinal study. Personnel Psychology, 54(1), 101-114. http://dx.doi.org/10.1111/j.1744-6570.2001.tb00087.x

Kramer, M. W. (1999). Motivation to reduce uncertainty: a reconceptualization of uncertainty reduction theory. Management Communication Quarterly, 13(2), 305-316. http://dx.doi.org/10.1177/0893318999132007

Lee, K. \& Allen, N. (2002). Organizational citizenship behaviour and workplace deviance: the role of affect and cognitions. Journal of Applied Psychology, 87, 131-142. http://dx.doi.org/10.1037/0021-9010.87.1.131

Litterst, J. K. \& Eyo, B. (1982). Gauging the effectiveness of formal communication programs: A search for the communication-productivity link. Journal of Business Communication, 19(2), 15-26. http://dx.doi.org/10.1177/002194368201900202

Malik, M. E., Naeem, B. \& Ali, B. B. (2011). How do workplace spirituality and organizational citizenship behaviour influence sales performance of FMCG sales force? Interdisciplinary Journal of Contemporary Research in Business, 3(8), 610-620.

Montgomery, D. C., Blodget, J. G. \& Barnes, J. H. (1996). A model of financial securities salespersons' job stress. The Journal of Services Marketing, 10(3), 21-38. http://dx.doi.org/10.1108/08876049610119776

Morrison, E. W. (1994). Role definitions and organizational citizenship behaviour: The importance of employees' perspective. Academy of Management Journal, 37, 1543-1567. http://dx.doi.org/10.2307/256798

Motowidlo, S. P., Packard, J. S. \& Manning, M. (1986). Occupational stress: its causes and consequences for job performance. Journal of Applied Psychology, 71, 618-629. http://dx.doi.org/10.1037/0021-9010.71.4.618

Nelson, D. L. \& Burke, R. J. (2000). Women executives: Health, stress, and success. Academy of Management Executive, 14(2), 107-121. http://dx.doi.org/10.5465/AME.2000.3819310

Okpara, J. O. (2007). The effect of culture on job satisfaction and organizational commitment: a study of information system managers in Nigeria. Journal of African Business, 18(1), 113-130. http://dx.doi.org/10.1300/J156v08n01_07

Orgaad, T., Marnburg, E. \& Larsen, S. (2008). Perception of organizational structure in the hospitality industry: Consequences for commitment, job satisfaction and perceived performance. Tourism Management, 29(4), 661-671. http://dx.doi.org/10.1016/j.tourman.2007.07.006

Organ, D. W. \& Ryan, K. (1995). A meta-analytic review of the attitudinal and dispositional predictors of $\begin{array}{lllll}\text { organizational citizenship behaviour. Personnel Pychology, 48, } & \text { 775-802. }\end{array}$ http://dx.doi.org/10.1111/j.1744-6570.1995.tb01781.x

Organ, D. W. (1988). Organizational citizenship behaviour: The good soldier syndrome. Lexington, MA: Lexington Books.

Organ, D. W. (1997). Organizational citizenship behaviour: It's construct clean-up time. Human Performance, 10(2), 85-97. http://dx.doi.org/10.1207/s15327043hup1002_2

Orpen, C. (1997). The interactive effects of communication quality and job involvement on managerial job satisfaction and work motivation. The Journal of Psychology, 131(5), 519-522. http://dx.doi.org/10.1080/00223989709603540

Pallie, P. (2011). Stressful work, citizenship behaviour and intention to leave the organization in a high turnover environment: examining the mediating role of job satisfaction. Journal of Management Research, 3(1), 1-14.

Park, J. (2007). Work stress and job performance. Perspectives, Decemmber, 5-7.

Penley, L. E. \& Hawkins, B. (1985). Studying interpersonal communication in organizations: a leadership application. Academy of Management Journal 28(2), 309-326. http://dx.doi.org/10.2307/256203

Podskaff, P. M., McKenzie, B. S., Paine, J. B. \& Bacharach, D. G. (2000). Organizational citizenship behaviours: A critical review of the theoretical and empirical literature and suggestions for future research. Journal of Management, 26, 513-563. http://dx.doi.org/10.1177/014920630002600307

Price, J. L. (1997). Handbook of organizational measurement. International Journal of Manpower 18(4-6), 303-558.

Rees, D. W. (1995). Workplace-related stress in health service employees. Journal of Managerial Psychology, 10(3), 4-11. http://dx.doi.org/10.1108/02683949510081329

Sparks, K. \& Cooper, C. L. (1999). Occupational differences in the work strain relationship: Towards the use of situation specific models. Journal of Occupational and Organizational Psychology, 72, 219-229.

Womboh, B. S. (2008). The state of ICT in Nigerian university libraries: the experience of IBB library, federal university of technology Yola, Nigeria. Library Philosophy and Practice. 